\title{
Comparison of Bone Mineral Density Levels in Maraş Powder (Smokeless Tobacco) Users and Smokers in Healthy Men
}

\author{
Sağlıkı Erkeklerde Maraş Otu (Dumansız Tütün) Kullanımı lle Sigara Kullanımının \\ Kemik Mineral Yoğunluğu Üzerine Olan Etkisinin Karşılaştırılması \\ Betül Bakan, Mustafa Haki Sucaklı*, Fuat Özkan**, Ökkeş Bilal***, Idris Altun**** \\ Sütçü Imam University Faculty of Medicine, Department of Physical Therapy and Rehabilitation, Kahramanmaraş, Turkey \\ * Sütçü Imam University, Faculty of Medicine, Department of Family Medicine, Kahramanmaraş, Turkey \\ ** Sütçü Imam University, Faculty of Medicine, Department of Radiology, Kahramanmaraş, Turkey \\ *** Sütçü Imam University Faculty Of Medicine, Department of Orthopedic Surgery and Traumatology, Kahramanmaraş, Turkey \\ ****Sütçü Imam University Faculty of Medicine, Department of Neurosurgery, Kahramanmaraş, Turkey
}

\section{Summary}

Aim: Smoking and smokeless tobacco use are two recognized risk factors for low bone mineral density (BMD) and osteoporosis. Maras powder (MP), a kind of smokeless tobacco, has a lot of addicts in the city of Kahramanmaraş and its surroundings, Turkey. This is the study investigating the effects of MP on BMD and comparing with smoking.

Meterial and Methods: A total of 120 healthy male subjects (60 MP users, 60 smoker) from Maras City, Turkey were included in the study. All subjects information on demographics, health history, alcohol and tobacco use and medication use were obtained by an interviewer-administered questionnaire. Subjects who had any pathology that might affect BMD, were excluded from the study. Measurements of bone mineral density were obtained by phalangeal radiographic absorptiometry of the nondominant hand. BMD values $\left(\mathrm{g} / \mathrm{cm}^{2}\right)$ of MP users were compared with those of smokers. Results: The mean duration of MP use and the mean age of MP users were 30.6 \pm 14.4 years and $64.4 \pm 9.8$ years, respectively. The mean duration of smoking and the mean age of smokers were $33.7 \pm 11.0$ years and $61.6 \pm 10.4$ years, respectively. The mean phalangeal BMD in MP users $\left(0.31 \pm 0.04 \mathrm{~g} / \mathrm{cm}^{2}\right)$ was significantly lower than that in the smokers $\left(0.33 \pm 0.03 \mathrm{~g} / \mathrm{cm}^{2}, \mathrm{p}=0.004\right)$.

Conclusion: In MP user males, BMD is lower compared to the smoker males. If our results are supported by other studies, it may be claimed that MP use is a very strong risk factor for low BMD value compared to cigarette smoking. (Turkish Journal of Osteoporosis 2013;19: 12-6) Key words: Maraş powder, smokeless tobacco, smoking, phalangeal radiographic absorptiometry, bone mineral density.

\section{Özet}

Amaç: Sigara ve dumansız tütün kullanımı düşük kemik mineral yoğunluğu (KMY) ve osteoporoz için tanımlanmış iki risk faktörüdür. Türkiye'de 'Maraş Otu' (MO) olarak adlandırılan dumansız tütün türünün, özelikle Kahramanmaraş ve çevresindeki illerde birçok bağımlısı bulunmaktadır. Bu çalışmada MO kullanımı ile sigara içiminin KMY üzerine olan etkisi araştııılı.

Gereç ve Yöntem: Yüz yirmi sağlıklı erkek (MO kullanan 60 kişi, sigara içen 60 kişi) çalışmaya alındı. Çalışmaya katılan kişilere; demografik bilgileri, sağlık durumları, alkol, tütün alışkanlıkları ve kullandıkları ilaçları sorgulayan bir anket formu uygulandı. KMY'yi etkileyecek herhengi bir patolojisi olanlar çalışma dışı bırakıldı. KMY non-dominant elden falangial radyografik absorbsiyometri cihazı ile ölçüldü. MO kullananların $\mathrm{KMY}\left(\mathrm{gr} / \mathrm{cm}^{2}\right)$ değerleri, sigara içenlerlerin KMY değerleri ile karşılaştııılı.

Bulgular: Ortalama MO kullanma süresi ve MO kullananların yaş ortalaması sırası ile $30,6 \pm 14,4$ yıl ve $64,4 \pm 9,8$ yıldı. Ortalama sigara kullanma süresi ve sigara kullananların yaş ortalaması sırası ile $33,7 \pm 11,0$ yıl ve $61,6 \pm 10,4$ yıldı. MO kullananların falangial KMY değerlerinin ortalaması $(0,31 \pm 0,04$ $\left.\mathrm{g} / \mathrm{cm}^{2}\right)$, sigara kullananlara $\left(0,33 \pm 0,03 \mathrm{~g} / \mathrm{cm}^{2}, \mathrm{p}=0,004\right)$ göre anlamlı derecede daha düşüktü.

Sonuç: MO kullanan erkeklerin KMY değerleri sigara kullananlara göre daha düşüktü. Sonuçlarımı başka çalışmalarla desteklenirse, MO kullanımı osteoporoz için sigaradan daha güçlü bir risk faktörü olduğu söylenebilir. (Türk Osteoporoz Dergisi 2013;19: 12-6)

Anahtar kelimeler: Maraş otu, dumansız tütün, sigara, falangial radyografik absorpsiyometri, kemik mineral yoğunluğu

Address for Correspondence / Yazışma Adresi: Betül Bakan MD, Sütçü İmam University Faculty of Medicine, Department of Physical Therapy and Rehabilitation, Kahramanmaraş, Turkey Phone: +90 3442212337 E-mail: berdembakan@gmail.com Received/Geliş Tarihi: 15.01.2013 Accepted/Kabul Tarihi: 21.02.2013

Turkish Journal of Osteoporosis, published by Galenos Publishing. /Türk Osteoporoz Dergisi, Galenos Yayınevi tarafindan basılmıştır. 


\section{Introduction}

Osteoporosis is a complex heterogeneous disorder characterized by an imbalance in bone remodeling which culminates in reduced bone mineral density (BMD), deterioration of microarchitectural integrity of the bone, and increased risk of fracture (1). It has a major economic and health impact. Osteoporotic fractures are associated with increased morbidity and mortality (2). A quick recovery from osteoporosis is not possible and osteoporosis increases the fracture risk. Hence, early diagnosis of osteoporosis is particularly important for the prevention of morbidity and mortality (3). Lowering an individual's risk for osteoporotic fracture must focus not only on the treatment but also on modification of risk factors (4). While some risk factors for this condition cannot be changed (e.g., family history of osteoporosis, age, gender, small body build) , many behavioral factors are modifiable (e.g., alcohol use, lifestyle) $(5,6)$. Smokeless tobacco (ST) use and smoking are two of the modifiable risk factors for osteoporosis $(3,6)$. ST use is prevelant among certain populations (4). While the prevalence of cigarette smoking has been declining in the United States, annual consumption of ST has nearly tripled in the past 20 years (7). According the National Household Survey on Drug Abuse, an estimated 8.2 million individuals older than 12 years of age $(3.2 \%)$ in the U.S. are current ST users. The prevalence of current ST use is $2.1 \%$ among youths aged 12 to $17,5.4 \%$ among 18 to 25 year olds. (8).

The habitual use of a type of ST named Maras powder (MP) is common in the southeast region of Turkey, especially in Kahramanmaras and other southeastern cities (9). The large majority of people from the region do not have information regarding the harmful effects of MP, yet they think it is not as harmful as cigarettes, which is a common belief. Since MP use generally starts in the adolescent, the duration of use is long. Recent school-based surveys indicate that the prevalence of MP use might be increasing in boys (10).

MP is prepared from the leaves of Nicotiana rustica L., a subspecies of Nicotiana, which is grown in the region. The plant has large $(15 \mathrm{~cm})$ and wrinkled leaves with yellow and green flowers (11). In order to prepare MP, the leaves are first dried and then beaten and shoots are mixed with ashes obtained from oak, walnut, or grape branches. A small amount of this mixture (approximately $1 \mathrm{~g}$ ) is placed between the gum and lower lip. After 5-6 min, the mixture is spat out, and this action is repeated many times throughout the day. Some users even sleep with the powder in their mouths (12). Nicotine content of Nicotiana rustica $L$ is about 6-10 fold higher than Nicotiana tobacum L., which is present in the cigarette

tobacco (9). MP use may have important public health implications in this area. Cigarette smoking is a well-established risk factor for osteoporosis. Despite the lack of research regarding MPs effect on osteoporosis and bone health, we hypothesized that MPs effect on bone health is similar to that of cigarette smoking and that it can be accepted as an additional risk factor for osteoporosis where its use is prevalent. In this study; the effect of MP use on BMD was compared with the effect of smoking on BMD.

\section{Materials and Methods}

This osteoporosis screening study was conducted in southeast region of Turkey and was done from September 2010 to November 2010. It was a cross -sectional study, approved by our hospital ethics committee, and a total of 120 healthy men, who were 50 or older years and cigarette smoking or using MP for at least 5 years agreed to participate in the study. All participants were informed about the nature of the study, and a signed consent form was obtained. Information on demographics, educational status, occupation, living area, health history, MP use, history of smoking and medications was obtained by an interviewer-administered questionnaire. We excluded those men who have any previous health problems; such as osteoporosis, hyperthyroidism, medication use (within last 3 years) with an effect on the phosphorus or calcium metabolisms (e.g., calcitonin, alendronate or hormone replacement of any type in the past year) and bone mass (e.g. corticosteroids, androgens, antiepileptics).

120 subjects; 60 people using MP and 60 cigarette smoker were evaluated and BMD was measured in nondominant hand by phalangeal radiographic absorptiometry (RA), as detailed below. Phalangeal BMD values of MP users were compared with those of the smokers.

\section{BMD Measurements}

BMD was measured on the middle phalanges of the second, third and fourth fingers on non-dominant hand, using an Alara MetriScan ${ }^{\circledR}$ phalangeal RA device (Alara Inc. Fremont, USA). Dual-energy X-ray absorbsiyometry (DXA) is the standart method for evaluating BMD. But axial DXA is inaccessible in many regions, relatively expensive and not portabl (13). Peripheral densitometry is an accessible and inexpensive method to measure phalengeal BMD in osteoporosis screening. Moreover it has the advantages of portability and low X-ray exposure $(<0.02 \mu \mathrm{Sv}$ per examination) (14). For an exposure, the patient removes any jewellery (when possible) from the non-dominant hand, and places the hand on the moulded support plate (13). The operator is able to take the exposure using either a button on the front of the device. After the system analyses the image and has segmented soft tissue and bone into separate components, the regions of interest are automatically identified and outlined (15). BMD is expressed in grams per square centimeter $\left(\mathrm{g} / \mathrm{cm}^{2}\right)(14)$.

\section{Statistical Analyses}

All data were analyzed using a descriptive analysis technique and an independent t-test for continuous variables. The Pearson (product-moment) and spearman correlation were used to identify predictors of low bone mass. $p$ value less than 0.05 was considered statistically significant. Analyses were performed using SPSS ${ }^{\circledR}$ version 15.0 for Windows (SPSS, Inc., Chicago, IL, USA). 


\section{Results}

Participant characteristics of the subjects are shown in Table 1. The mean age of MP users group was $64.4 \pm 9.8$ (range:50 to 84 ) years; the mean duration of MP use was $30.6 \pm 14.4$ (range:5 to 60) years; the mean amount of MP used daily was $1.13 \pm 0.4$ (range:0.5 to 2) packet. Phalangeal BMD in MP users $0.31 \pm 0.04$ (range: 0.23 to 0.38 ) $\mathrm{g} / \mathrm{cm}^{2}$. The mean ages of the smoker group was $61.6 \pm 10.4$ (range: 50-84) years; the mean duration of smoking was $33.7 \pm 11.0$ (range: $5-60$ ) years; the mean amount of cigerette used daily was 1.03 \pm 0.5 (range: 0.5-2) packet. Phalangeal BMD in smoker group 0,33 $\pm 0,03$ (range: $0.24-0-40$ ) $\mathrm{g} / \mathrm{cm}^{2}$; When both groups were compared age, duration of habit, daily use the amount packet of habit, educational status and distribution of lifestyle forms were similar $(p=0.126, p=0.189, p=0.205, p=0.422, p=0.194$ respectively). But phalangeal $\mathrm{BMD}$ in MP users was significantly lower than that in the smoker $(p=0.004)$.

Correlation analysis was performed among four variables (Table 2): phalangeal BMD of subject, the age, the duration of tobacco use and the daily amount of tobacco (packet). Phalangeal BMD of the MP users was negatively correlated to the age $(r=-0.345$, $p=0.007)$, the duration of MP use $(r=-0.364, p=0.004)$ and the daily amount of MP $(r=-0.458, p=0.011)$. Phalangeal BMD of the smokers was negatively correlated to the age $(r=-0.448$, $p=0.00)$, the duration of cigarette use $(r=-0.295, p=0.022)$ and the daily amount of cigarette

$(r=-0.393, p=0.002)$.

\section{Discussion}

Osteoporosis has traditionally been a disorder almost synonymously associated with postmenopausal women. Nevertheless, in the last decade, it has been acknowledged that the problem of osteoporosis in men represents an important public health issue $(16,17)$. In recent studies, the prevalence of osteoporosis in men older than 50 years old was about 6\% (18) and fatalities caused by femoral neck fracture were more common in men than in women (19). In addition, osteoporosis in elderly men has become an important disease because one study found that $25 \%$ of men were in danger of fracture due to osteoporosis (20). This study was done to explore the effect of MP use and smoking on BMD in men in the southeast region of Turkey. We found that male MP users have significantly lower BMD than cigarette smokers. Our result is similar to previous studies done females which showed that ST users had significantly lower BMD than smokers $(3,6)$.

Quandt et al.(6) studied risk factors for low BMD among older women in a multi-ethnic population, and they reported that ST

Table 1. Descriptive statistics for participant characteristics $\left({ }^{* *} p<0.01\right)$

\begin{tabular}{|c|c|c|c|}
\hline Characteristic & $\begin{array}{c}\text { Maraş powder users } \\
\text { n: }=60\end{array}$ & $\begin{array}{c}\text { Smoker } \\
n=60\end{array}$ & $p$ \\
\hline $\begin{array}{l}\text { Age (years); } \\
\text { mean }( \pm S D) \\
(\text { min-max })\end{array}$ & $\begin{array}{l}64.4 \pm 9.8 \\
(50-84)\end{array}$ & $\begin{array}{c}61.6 \pm 10.4 \\
(50-84)\end{array}$ & 0.126 \\
\hline $\begin{array}{l}\text { Duration of tobacco use (years); } \\
\text { mean }( \pm S D) \text {, } \\
\text { (min-max) }\end{array}$ & $\begin{array}{c}30.6 \pm 14.4 \\
5-60\end{array}$ & $\begin{array}{l}33.7 \pm 11.0 \\
5-60\end{array}$ & 0.189 \\
\hline $\begin{array}{l}\text { Daily use the amount of tobacco }\left(\text { packet }^{*}\right) \text {; } \\
\text { mean }( \pm S D) \text {, } \\
\text { (min-max) }\end{array}$ & $\begin{array}{c}1.13 \pm 0.4 \\
0.5-2\end{array}$ & $\begin{array}{c}1.03 \pm 0.5 \\
0.5-2\end{array}$ & 0.205 \\
\hline $\begin{array}{l}\text { Education; } \\
<\text { High school } \\
\text { High school }\end{array}$ & $\begin{array}{l}45 \\
15\end{array}$ & $\begin{array}{c}41 \\
19\end{array}$ & 0.422 \\
\hline $\begin{array}{l}\text { Live area; } \\
\text { Rural } \\
\text { Urban }\end{array}$ & $\begin{array}{l}27 \\
33\end{array}$ & $\begin{array}{l}20 \\
40\end{array}$ & 0.194 \\
\hline $\begin{array}{l}\mathrm{BMD}\left(\mathrm{g} / \mathrm{cm}^{2}\right) \\
\text { mean }( \pm \mathrm{SD}) \\
(\min -\max )\end{array}$ & $\begin{array}{l}0.31 \pm 0.04 \\
0.23-0.38\end{array}$ & $\begin{array}{l}0.33 \pm 0.03 \\
0.24-0.40\end{array}$ & $0.004^{* *}$ \\
\hline
\end{tabular}


Table 2. Correlation between bone mineral density and related variables

\begin{tabular}{|l|l|l|l|}
\hline & $X 1$ & $X 2$ & $X 3$ \\
\hline$Y 1$ & $r=-0.345^{\star *}$ & $r=-0.364^{* *}$ & $r=-0.458^{* *}$ \\
& $p=0.007^{a}$ & $p=0.004^{b}$ & $p=0.011^{a}$ \\
\hline$Y 2$ & $r=-0.448^{\star *}$ & $r=-0.295^{\star *}$ & $r=-0.393^{* *}$ \\
& $p=0.00^{a}$ & $p=0.022^{b}$ & $p=0.002^{a}$ \\
\hline
\end{tabular}

Date are presented as the $r$ and $p$ value in pearson ${ }^{a}$ and spearman ${ }^{b}$ correlation test ${ }^{*} p<0.05$ level (2-tailed).

$* * p<0.01$ level (2-tailed)

Y1: Phalangeal BMD of the MP users Y2: Phalangeal BMD of the smokers X1: Age X2: Duration of tobacco use X3: Daily amount of tobacco (packet).

should be considered as a potential additional risk factor for osteoporosis in populations where its use is prevalent.

Factors implicated in the pathogenesis of bone loss in men are not well understood, and environmental risk factors probably do not differ greatly between women and men (17). Numerous studies have linked smoking with low BMD, osteoporosis and osteoporotic fracture. Initial reports indicated that men and women who smoked had lower BMDs than nonsmokers of the same age and sex $(2,4,17)$. Although the effects of cigarette smoking on BMD and osteoporosis have been described (15), a similar effect of ST use on osteoporosis has rarely been investigated. (4). if nicotine or another component from ST use has similar adverse effects on bone as cigarette smoking, MP use delivers higher doses of nicotine to users than does cigarette smoking (21). It might be more likely to exert adverse nicotine effects on the bones of MP users compared with those who smoked cigarettes. Although the exact mechanism for this effect is unknown, there may be several possible explanations (6). Nicotine induces vasoconstriction, causes low tissue oxygen tension, leads tissue ischemia and negatively affect osteoblastic bone formation and increases osteoclastic bone resorption $(2,6)$. Additionally, non-nicotine constituents of tobacco have a direct effect on bone cells $(22,23)$. In vitro studies have shown that cigarette smoke extract inhibits osteoblast-like cell proliferation and differentiation as well as bone repair and remodeling (22). Nicotine has an inhibitory effect on osteogenesis but may also have the same effect on angiogenesis, which can play a detrimental role in bone dynamics. An in vitro study, using nicotine pellets in rabbits, showed that nicotine not only had a dose dependent inhibitory effect on rabbit osteoblast cell proliferation but also on transforming growth factor$\beta$ 1, bone morphogenetic protein-2, platelet -derived growth factor-AA, and vascular endothelial growth factor. The latter factors play a role in either osteogenesis or angiogenesis (24). In addition, impaired bone formation in smokers may be directly attributed to defective collagen synthesis $(2,25)$.

Animal studies provide justification for investigating the relationship between ST use and osteoporosis. Galvin et al. (26) found that both a ST extract (STE) and a nicotine-free
STE inhibited bone oxygen consumption, increased glycolysis and lactate production, and reduced collagen synthesis in chick embryo tibiae preparations. High concentrations of nicotin itself decreased bone oxygen consumption and collagen synthesis, but glycolysis was not altered leading the investigators to conclude that nicotine was not responsible for all effects of the STE. The authors hypothesized that this acute STE-bone metabolism model would be most relevant to the oral cavity where high concentrations of ST come in direct contact with bone. It is found that any tobacco use increases alveolar bone loss in the oral cavity (27) and this relationship is dose dependent (28). This effect may be the result of inhibition of collagen synthesis by nicotine $(29,30)$. Greater exposure to cigarettes (expressed as number of years as a smoker, cigarettes per day or pack-years) has been associated with greater decline in BMD at multiple skeletal sites in a large meta-analysis $(2,30,31)$.

In conclusion, BMD is lower in MP user males compared with smoker males.

Our results suggested that MP appears to be a more potent risk factor for low BMD value than cigerette smoking in populations where their use is prevalent.

Limitation of our study is the lack of control group of nonsmokers of the same age and sex.

\section{Kaynaklar}

1. Kutsal YG. Erkeklerde osteoporoz. Kutsal YG, editör. Osteoporoz. 2. basım. Ankara: Güneş kitabevi; 2005.s.183-94.

2. Yoon V, Maalouf NM, Sakhaee K. The effects of smoking on bone metabolism. Osteoporos Int 2012:23:2081-92

3. Seo HJ, Kim SG, Kim CS. Risk factors for bone mineral density at the calcaneus in 40-59 year-old male workers: a cross-sectional study in Korea. BMC Public Health 2008;8:253.

4. Spangler JG, Quandt S, Bell RA. Smokeless tobacco and osteoporosis: a new relationship? Med Hypotheses 2001;56:553-7.

5. Kanis JA. New osteoporosis guidelines for Canada. CMAJ 2010;182:1829-30.

6. Quandt SA, Spangler JG, Case LD, Bell RA, Belflower AE. Smokeless tobacco use accelerates age-related loss of bone mineral density among older women in a multethnic rural community. J Cross Cult Gerontol 2005;20:109-25.

7. Office of the Inspector General. Spit tobacco and youth. 1992 Anonymous. Washington, D.C. Dept. of Health and Human Services. OEI 06-92-00500.

8. Substance Abuse and Mental Health Services Administration, Results from the 2011 National Survey on Drug Use and Health: Summary of National Findings, NSDUH Series H-44, HHS Publication No. (SMA) 12-4713. Rockville, MD: Substance Abuse and Mental Health Services Administration, 2012.

9. Kurtul N, Gökpınar E. Salivary lipid peroxidation and total sialic acid levels in smokers and smokeless tobacco users as Maraş powder. Mediators Inflamm 2012;2012:619293.

10. Sarıkaya A, Ceyhan OF, Dölek I. Maras Powder usage habits of high school students Research, 2010 TUBITAK secondary education project competition.

11. Ozkul Y, Donmez H, Erenmemisoglu A, Demirtas $H$, Imamoglu N. Induction of micronuclei by smokeless tobacco on buccal mucosa cells of habitual users. Mutagenesis 1997;12:285-7.

12. Saatci C, Ozkul Y, Tahiri S, Caglayan AO, Turhan AB, Dundar $M$. The effect of Maras powder on DNA methylation and micronucleus formation in human buccal tissue. J Toxicol Environ Health A 2008;71:396-404. 
13. Hüner B, Özgüzel MH, Atar S. Osteoporoz tanısında falangeal absorpsiyometri tekniğinin dual enerji x-ışını absorpsiyometri tekniği ile karşılaştırılması. Türk Fiz Tıp Rehab Derg 2009;55:68-72.

14. Holmberg $T$, Bech M, Curtis T, Juel K, Gronbaek M, Brixen K. Association between passive smoking in adulthood and phalangeal bone mineral density: results from the KRAM studythe Danish Health Examination Survey 2007-2008. Osteoporos Int 2011;22:2989-99.

15. Boonen S, Nijs J, Borghs $H$, Peeters $H$, Vanderschueren D, Luyten FP. Identifying postmenopausal women with osteoporosis by calcaneal ultrasound, metacarpal digital X-ray radiogrammetry and phalangeal radiographic absorptiometry: a comparative study. Osteoporos Int 2005;16:93-100.

16. Dilşen G. Türkiye'de osteoporoz. Kutsal YG, editör. Osteoporoz. 2. basım. Ankara: Güneş kitabevi; 2005.s. 315-56.

17. Ortego-Centeno N, Muñoz-Torres M, Jódar E, Hernández-Quero J, Jurado-Duce A, de la Higuera Torres-Puchol J. Effect of tobacco consumption on bone mineral density in healthy young males. Calcif Tissue Int 1997;60:496-500.

18. Hadji P, Klein S, Gothe H, Haussler B, Kless T, Schmidt T, et al. The Epidemiology of Osteoporosis-Bone Evaluation Study (BEST): An Analysis of Routine Health Insurance Data. Dtsch Arztebl Int 2013;110:52-7.

19. Kelepouris N, Harper KD, Gannon F, Kaplan FS, Haddad JG. Severe osteoporosis in men. Ann Intern Med 1995;123:452-60.

20. Nguyen TV, Eisman JA, Kelly PJ, Sambrook PN. Risk factors for osteoporotic fractures in elderly men. Am J Epidemiol 1996;144:255-63.

21. Cok I, Oztürk R. Urinary cotinine levels of smokeless tobacco (Maraş powder) users. Hum Exp Toxicol 2000;19:650-5.
22. Liu X, Kohyama T, Kobayashi T, Abe S, Kim HJ, Reed EC, et al. Cigarette smoke extract inhibits chemotaxis and collagen gel contraction mediated by human bone marrow osteo progenitorcells and osteoblast- like cells. Osteoporos Int 2003;14:235-42.

23. Ajiro Y, Tokuhashi Y, Matsuzaki H, Nakajima S, Ogawa T. Impact of passive smoking on the bones of rats. Orthopedics 2010;33:90-5.

24. Ma L, Zheng LW, Sham MH, Cheung LK. Uncoupled angiogenesis and osteogenesis in nicotine-compromised bone healing. J Bone Miner Res 2010;25:1305-13.

25. Sorensen LT, Toft BG, Rygaard J, Ladelund S, Paddon M, James $\mathrm{T}$, et al. Effect of smoking, smoking cessation, and nicotine patch on wound dimension, vitamin C, and systemic markers of collagen metabolism. Surgery 2010;148:982-90.

26. Galvin RJ, Ramp WK, Lenz LG. Smokeless tobacco contains a nonnicotine inhibitor of bone metabolism. Toxicol Appl Pharmacol 1988;95:292-300.

27. Burgan SW. The role of tobacco use in periodontal diseases: A literature review. Gen Dent 1997:45:449-60.

28. Hopper JL, Seeman E. The bone density of female twins discordant for tobacco use. N Engl J Med 1994;330:387-92

29. Flicker L, Hopper JL, Rodgers L, Kaymakci B, Green RM, Wark JD. Bone density determinants in elderly women: a twin study. J Bone Miner Res 1995;10:1607-13.

30. Bergstrom J, Dock J, Eliasson S, Hatlin M. Tobacco smoking and periodontal disease: cross-sectional and longitudinal aspects. J Dent Res 1994;73:187.

31. Lenz LG, Ramp WK, Galvin RJ, Pierce WM Jr. Inhibition of cell metabolism by smokeless tobacco extract: tissue and species specificity. Proc Soc Exp Biol Med 1992;19:211-7. 